\title{
Hemangiomas and laser therapy: clinical experience
}

\author{
A Greto Ciriaco ${ }^{*}$, M Vonella, T Vitagliano, M A Fiorillo, D Novembre, M Greco \\ From de Senectute: Age and Health Forum \\ Catanzaro, Italy. 5-7 December 2009
}

\section{Background}

Hemangiomas are common benign vascular tumors characterized by a proliferative growth phase followed by very slow and inevitable regression. They are classified as capillary, cavernous, and mixed lesions, $60 \%$ are localized on the head and neck but they can be found in all regions of the body. Most of the lesions are focal and solitary, while $15 \%-20 \%$ are multiple with involvement of extracutaneous sites. Although hemangioma is usually benign, its growth is very unpredictable, due to uncontrollable endothelial cell proliferation, and complications are frequent because hemangiomas can evolve in ulceration. We present our clinical experience on the role of lasers to treat port wine stains, superficial hemangiomas, and café au lait macules.

\section{Material and methods}

Literature 1 reports many treatment modalities including close observation, drug therapy, sclerotherapy (steroids, bleomycin), cryotherapy, radiotherapy, laser therapy, and surgical therapy. There still exist many controversies over the optimal treatment options for individual patient. Betwen 2005 and 2009 we used differents types of laser therapy, indicated in proliferative hemangiomas, to treat 103 patients. The flash lamp pulsed dye laser $(585 \mathrm{~nm})$ has been used successfully in ulcerated lesions. The Nd:YAG laser $(1060 \mathrm{~nm}) 2$, which penetrates deeper in the tissues, produce considerable scarring. Scarring appears to be less with a tunable dye laser $(577 \mathrm{~nm})$.

\section{Results}

After 6 months of follow-up from the first session of laser treatment, total resolution was obtained in 72 patients. A second or third session followed in 29

\footnotetext{
Department of Plastic Surgery, "University Magna Graecia", Catanzaro, 88100,
} Italy patients in which, the initial results were good, moderate, or poor. Two patients refused refused the second session. Complications were seen in nine patients. One patient had postoperative bleeding which stopped spontaneously, while atrophic scars occurred in six patients, and hypertrophic scars in two patients.

\section{Conclusions}

$\mathrm{Nd}$ :YAG laser irradiation produces good cosmetic results for the treatment of cutaneous hemangiomas. Best results are obteined if patient epidermis are ice protected. That decreases the number of sessions for treatment of these lesions.

\section{Published: 19 May 2010}

\section{References}

1. Civas E, Koc E, Aksoy B, Aksoy HM: Clinical Experience in the Treatment of Different Vascular Lesions Using a Neodymium-Doped Yttrium Aluminum Garnet Laser. Dermatol Surg. 2009, 3.

2. Tierney EP, Kouba DJ, Hanke CW: Review of fractional photothermolysis: treatment indications and efficacy. Dermatol Surg. 2009, 35(10):1445-1461.

doi:10.1186/1471-2318-10-S1-A62

Cite this article as: Ciriaco et al:: Hemangiomas and laser therapy: clinical experience. BMC Geriatrics 2010 10(Suppl 1):A62.

Submit your next manuscript to BioMed Central and take full advantage of:

- Convenient online submission

- Thorough peer review

- No space constraints or color figure charges

- Immediate publication on acceptance

- Inclusion in PubIMed, CAS, Scopus and Google Scholar

- Research which is freely available for redistribution

Submit your manuscript at www.biomedcentral.com/submit 